\title{
Pengukuran Customer Satisfaction Index Terhadap Pelayanan di Century Gym
}

\section{Measurement of Customer Satisfaction Index of Service in Century Gym}

\author{
I gede kt. Tjahyadi Putra Budhi ${ }^{1}$, Ni Kadek Sumiari ${ }^{2}$ \\ Program Studi Manajemen Informatika \\ STMIK STIKOM Bali \\ Jl. Raya Puputan no 86 Renon - Denpasar \\ tjahyadi@stikom-bali.ac.id, sumiari@stikom-bali.ac.id
}

\begin{abstract}
Abstrak
Kepuasan adalah penilaian terhadap suatu produk dengan membandingkan kenyataan dan harapan pada produk tersebut. Kepuasan pelanggan berpengaruh terhadap loyalitas dan kesetiaan pelanggan. Kepuasan Pelanggan memberikan dampak positif pada kelangsungan suatu organisasi dan dapat memberikan rekomendasi kepada calon pelanggan yang baru. Pengukuran tingkat kepuasan pelanggan adalah salah satu cara dari century Gym untuk menjaga kualitas pelayanan terhadap pelanggan.Customer Satisfaction Index adalah metode untuk mengukur kepuasan pelanggan berdasarkan atribut yang akan diukur seperti keandalan, daya tanggap, jaminan, dan empati. Tujuan dari penelitian adalah untuk meningkatkan kinerja pelayanan, fasilitas dan penanganan keluhan pelanggan dari Century Gym. Hasil dari penelitian ini adalah perhitungan tingkat kepuasan pelanggan di Century Gym yang dinilai dari atribut bukti fisik (tangible) keandalan (reliability), daya tanggap (responsiveness), jaminan (assurance), dan empati (emphaty). Hasil yang diperoleh dari penelitian ini adalah persetase tingkat kepuasan konsumen dari kelima atribut tersebut. Perhitungan ini bermanfaat bagi organisasi untuk mengetahui tingkat kepentingan pelanggan dan kinerja organisasi menurut persepsi pelanggan. Selain itu dengan adanya penelitian ini juga bisa diketahui kualitas pelayanan yang perlu ditingkatkan dan mendorong upaya peningkatan kualitas pelayanan untuk meningkatkan kepuasan pelanggan century gym.
\end{abstract}

Kata kunci-Kepuasan, Pelanggan, gym

Satisfaction is the assessment of a product by comparing the reality and expectations of the product. Customer satisfaction effect on loyalty and customer loyalty. Customer satisfaction have a positive impact on the viability of an organization and can give recommendations to prospective new customers. Measuring the level of customer satisfaction is one of the ways of the century Gym to maintain the quality of service to pelanggan.Customer Satisfaction Index is a method for measuring customer satisfaction will be measured based on attributes such as reliability, responsiveness, assurance, and empathy. The purpose of the research is to improve the performance of the services, facilities and handling of customer complaints of Century Gym. Results from this study is the calculation of the level of customer satisfaction in Century Gym assessed on the attributes of physical evidence (tangible) reliability (reliability), responsiveness (responsiveness), assurance (assurance), and empathy (empathy). The results obtained from this study is persetase fifth level of customer satisfaction of these attributes. This calculation is useful for organizations to determine the level of customer interest and organizational performance as perceived by the customer. In addition to the research also can be known the quality of service needs to be improved and to encourage efforts to improve the quality of service to enhance customer satisfaction gym century.

Keywords - Satisfaction, Customer, Gymnastic. 


\section{PENDAHULUAN}

Kepuasan adalah perasaan senang atau kecewa seseorang yang berasal dari perbandingan antara kesannya terhadap kinerja yang dirasakan dari suatu produk (perceived performance) dan harapan harapannya. Dengan adanya kepuasan pelanggan tersebut maka akan berdampak pada loyalitas dan kesetiaan pelanggan, sehingga memberikan dampak positif pada kelangsungan suatu organisasi dan dapat memberikan rekomendasi kepada calon pelanggan yang baru. Kepuasan pelanggan adalah pertahanan paling baik melawan persaingan bisnis.Perusahaan yang berhasil menjaga agar pelanggannya selalu puas hampir tidak terkalahkan dalam bisnis.Para pelanggan yang puas biasanya lebih setia, lebih sering membeli, dan rela membayar lebih banyak untuk membeli produk atau jasa perusahaan tersebut.Umumnya mereka tetap menjadi pelanggan apabila perusahaan itu sedang mengalami kesulitan, sehingga ada waktu bagi perusahaan untuk menyesuaikan diri pada perubahan. Mulanya konsep kepuasan dekat dengan kegiatan pemasaran karena adanya orientasi pemasaran terhadap kebutuhan pelanggan. Definisi kepuasan opersional yang banyak digunakan termasuk yang dikemukakan oleh Kotler. Kotler dan Keller (2006) mendefinisikan kepuasan sebagai perasaan senang atau kecewa yang berasal dari perbandingan antara persepsi (perception) terhadap hasil (perfomance) suatu produk dengan harapannya (expectation). harus digarisbawahi bahwa jauh sebelum ini (Oliver, 1977, 1981, Olson dan Dove, 1979, Tse dan Wilton, 1988) dalam Parker dan Mathews (2001) menyatakan bahwa pendekatan terhadap kepuasan dapat dilihat dari dua sisi yaitu kepuasan sebagai hasil (outcome) dan kepuasan sebagai proses dimana penyedia jasa memberikan pelayanan kepada Pelanggan. Dan menurut Kotler dan Keller (2006) secara implisit meyakini tiga hal: Nilai Pelanggan, Kepuasan dan Loyalitas. Semakin tinggi nilai yang diterima pelanggan, akan semakin tinggi pula tingkat kepuasan, dan sebagai akibatnya pelanggan akan semakin loyal. Untuk itu, Horn (2002) membagi telaah konsep kepuasan menjadi model makro dan mikro. Wahyuni (2007) menyimpulkan bahwa kepuasan menjadi faktor dependen dimana determinannya antara peneliti dapat berbeda, tergantung kepada titik pandang dan kesesuaian dengan permasalahan penelitian.

Salah satu metode yang bisa digunakan untuk melakukan pengukuran terhadap kepuasan pelanggan adalah Customer Satisfaction Index (CSI) yaitu merupakan metode yang menggunakan indeks untuk mengukur tingkat kepuasan konsumen berdasarkan atribut-atribut tertentu. Customer satisfaction index (CSI) adalah analisis kuantitatif berupa persentase pelanggan yang senang dalam suatu survei kepuasan pelanggan. CSI diperlukan untuk mengetahui tingkat kepuasan pelanggan secara keseluruhan dengan memperhatikan tingkat kepentingan dari atribut-atribut produk atau jasa.

Pusat olahraga merupakan salah satu usaha yang memiliki customer tetap dan sangat tergantung dari penilaian customer. Banyaknya pusat olahraga yang bermunculan di kota Denpasar menjadikan para pelaku bisnis dibidang tersebut berlomab-lomba memberikan fasilitas terbaik untuk menarik minat customer. Century GYM merupakan salah satu pusat olahraga yang ada di daerah Denpasar yang menyediakan pelayanan kebugaran badan yaitu fitnes. Century GYM berdiri tahun 2002 yang berada di Jl. Kebo Iwa Padang Sambian Kaja Denpasar Barat. Century GYM didirikan oleh Bapak Made Sugandi yang dulunya sering bergelut di dunia olahraga angkat berat. Century GYM memiliki ribuan customer akan tetapi setiap bulannya selalu penurunan dan peningkatan yang kurang stabil. Hal ini dikarenakan belum pernah dilakukan pengukuran kepuasan pelanggan yang ada di Century Gym agar pihak perusahaan bisa meningkatkan kualitas dan pelayanan untuk pelanggan.

Berdasarkan latarbelakang di atas pada penelitian ini dilakukan pengukuran kepuasan pelanggan pada Century Gym. Pengukuran kepuasan pelanggan yang dilakukan menggunakan Customer Satisfaction Index (CSI). Dimana metode penelitian yang digunakan adalah dengan menggunakan tools angket atau kuesioner yang disebar ke pelanggan Century Gym. Variable 
yang akan diukur untuk menentukan tingkat kepuasan pelanggan adalah menggunan pengukuran kepuasan pelanggan yang terdiri dari bukti fisik (tangible) keandalan (reliability), daya tanggap (responsiveness), jaminan (assurance), empati (emphaty) yang ada di Century Gym Hasil dari penelitian ini adalah berupa hasil perhitungan kepuasan pelanggan dengan menggunakan Customer Satisfaction Indeks (CSI). Perhitungan ini bermanfaat bagi organisasi untuk mengetahui tingkat kepentingan pelanggan dan kinerja organisasi menurut persepsi pelanggan serta mengetahui atribut kualitas pelayanan apa yang perlu ditingkatkan dan mendorong upaya perbaikan dan peningkatan kualitas pelayanan, dalam meningkatkan kepuasan pelanggan Century gym.

\subsection{Tinjauan Pustaka/ State of the Art Kepuasan}

Kepuasan adalah perasaan senang atau kecewa seseorang yang berasal dari perbandingan antara kesannya terhadap kinerja yang dirasakan dari suatu produk (perceived performance) dan harapan harapannya (Expectations). Kepuasan maupun ketidakpuasan merupakan penilaian purna pembelian, dimana alternative yang dipilih sekurang-kurangnya sama atau melampaui harapan pelanggan

Kepuasan pelanggan merupakan suatu tingkatan dimana kebutuhan, keinginan dan harapan dari pelanggan dapat terpenuhi yang akan mengakibatkan terjadinya pembelian ulang atau kesetiaan yang berlanjut. Kepuasan pelanggandapat didefinisikan sebagai respon efektif terhadap pengalaman melakukan konsumsi yang spesifik atau suatu evaluasi kesesuaian atau ketidak sesuaianyang dirasakan antara harapan sebelumnya dan kinerja aktual produk setelah pemakaian.

Harapan itu sendiri,dapat didefinisikan sebagai kepercayaan seseorang terhadap kemampuan suatu produk pada suatu waktu di masa yang akan datang. Semakin berkualitas produk dan jasa yang diberikan, maka kepuasan yang dirasakan oleh pelanggan semakin tinggi.Bila kepuasan pelanggan semakin tinggi, maka dapat menimbulkan keuntungan bagi badan usaha tersebut. Demikian pula sebaliknya, jika tanpa ada kepuasan, maka dapat mengakibatkan pelanggan pindah ke perusahaan lain.Adapun kepuasan pelanggan akan memberikan beberapa manfaat antara lain

1. Hubungan antara perusahaan dan para pelanggan menjadi harmonis.

2. Memberikan dasar yang baik bagi pembelian ulang.

3. Dapat mendorong terciptanya loyalitas pelanggan.

4. Membentuk suatu rekomendasi dari mulut ke mulut yang menguntungkan bagi perusahaan.

5. Reputasi perusahaan menjadi baik di mata pelanggan.

6. Laba yang diperoleh menjadi meningkat.

Faktor faktor yang mempengaruhi kepuasan dan ekspetasi pelanggan terdiri dari :

1. Kebutuhan dan keinginan yang berkaitan dengan hal-hal yang dirasakan pelanggan ketika ia sedang mencoba melakukan transaksi dengan produsen jasa. Jika pada saat itu kebutuhan dan keinginannya besar, harapan atau ekspetasi pelanggan akan tinggi, demikian pula sebaliknya.

2. Pengalaman masa lalu ketika menggunakan jasa pelayanan dari organisasi jasa maupun pesaing-pesaingnya.

3. Pengalaman dari teman-teman, yang menceritakan mengenai kualitas layanan jasa yang dirasakan berisiko tinggi.

4. Komunikasi melalui iklan dan pemasaran juga mempengaruhi pelanggan.

Untuk perusahaan yang berfokus pada pelanggan, kepuasan pelanggan adalah sasaran, ada beberapa metode yang biasa dipergunakan untuk mengukur dan memantau kepuasan pelanggan dari pelanggan pesaing yaitu :

1. Complain and Suggestion System (Sistem Keluhan dan Saran) 
Organisasi yang berorientasi pada pelanggan perlu menyediakan kesempatan dan akses yang mudah dan nyaman bagi pelanggannya guna menyampaikan saran, kritik, pendapat dan keluhan merek. Media yang digunakan biasanya berupa kotak saran yang ditempatkan dilokasilokasi strategis, kartu komentar, saluran telepon khusus bebas pulsa, website dan yang lainnya.

2. Ghost Shoping (Pembeli Bayaran)

Dalam hal ini perusahaan memperkerjakan beberapa orang Ghost Shoper untuk berperan atau berpura-pura sebagai pelanggan potensial produk perusahaan dan pesaing. Mereka diminta berinteraksi dengan staf penyedia jasa dan menggunakan jasa perusahaan. Berdasarkan pengalaman tersebut, mereka diminta dilaporkan laporan-laporannya mengenai kekuatan dan kelemahan produk perusahaan dan pesaing.

3. Lost Customer Analysis (Analisis Pelanggan yang Hilang)

Perusahaan menghubungi para pelanggan yang telah berhenti atau telah berpindah keperusahaan produk lain. Selain exit interview untuk mengungkap alasan pelanggan berpindah, perlu juga dilakukan pemantauan customer loss rate. Peningkatan customer loss rate menunjukkan kegagalan perusahaan dalam memuaskan pelanggan. Dengan metode ini akan diperoleh informasi yang dapat digunakan untuk memperbaiki kinerja perusahaan untuk mempertahankan konsumen dan meningkatkan kepuasan mereka.

4. Customer Satisfaction Survey (Survei Kepuasan Pelanggan)

Riset kepuasan pelanggan dapat dilakukan dengan metode survey melalui pos, telepon, e-mail, website, maupun wawancara langsung. Melalui survey, perusahaan akan memperoleh tanggapan dan umpan balik secara langsung dari pelanggan serta memberikan kesan positif bahwa perusahaan menaruh perhatian pada para pelanggan.

\section{Kualitas Pelayanan}

Kualitas pelayanan merupakan tingkat keunggulan yang diharapkan pelanggan. Apabila pelayanan yang diterima atau dirasakan sesuai dengan yang diharapkan, maka kualitas pelayanan dikatakan baik dan memuaskan. Sebaliknya, apabila pelayanan yang diterima atau dirasakan tidak sesuai dengan yang diharapkan, maka kualitas pelayanan dikatakan buruk atau tidak memuaskan.

Ada beberapa konsep mengenai dimensi kualitas pelayanan yang sering dipakai adalah berasal dari Parasuraman, dkk (1988), yang menunjukkan bahwa kualitas pelayanan adalah suatu pengertian yang multidimensi. Beberapa dimensi yang sering digunakan oleh para peneliti yaitu:

1. Reliability (keandalan), yaitu kemampuan untuk memberikan pelayanan sebagaimana yang dijanjikan secara tepat. Hal ini meliputi janji mengenai pelayanan yang baik, penanganan terhadap keberatan yang tepat dan cepat serta penggunaan komunikasi pasca pelayanan.

2. Responsiveness (Daya Tangkap), yaitu kemauan untuk membantu dan memberikan pelayanan yang baik pada pelanggan. Dimensi ini menekankan pada perilaku personil yang memberi pelayanan untuk memperhatikan permintaan-permintaan, pertanyaan dan keberatan-keberatan dari para pelanggan.

3. Assurance (jaminan), yaitu dimensi kualitas pelayanan yang berfokus pada kemampuan untuk melahirkan kepercayaan dan keyakinan pada diri pelanggan. Jaminan juga berarti bahwa karyawan selalu bersikap sopan dan menguasai pengetahuan dan keterampilan yang dibutuhkan untuk menangani setiap pertanyaan atau masalah pelanggan.

4. Empathy (Empati), yaitu aspek yang menekankan pada perlakuan konsumen sebagai individu, memahami kebutuhan pelanggan dan rasa peduli untuk memberikan perhatian secara individual.

Tangibles (Bukti Langsung), yaitu dimensi pelayanan yang berfokus pada elemen-elemen yang merepresentasikan pelayanan secara fisik. Dimensi ini meliputi fasilitas fisik (arsitektur gedung, 
warna, dekorasi, tempat parkir), perlengkapan (teknologi yang digunakan), merk (logo yang mudah diingat), lokasi, serta penampilan karyawan.

\subsection{Metode Penelitian}

\section{Sistematika Penelitian}

Adapun tahapan-tahapan yang akan dilakukan adalah sebagai berikut :

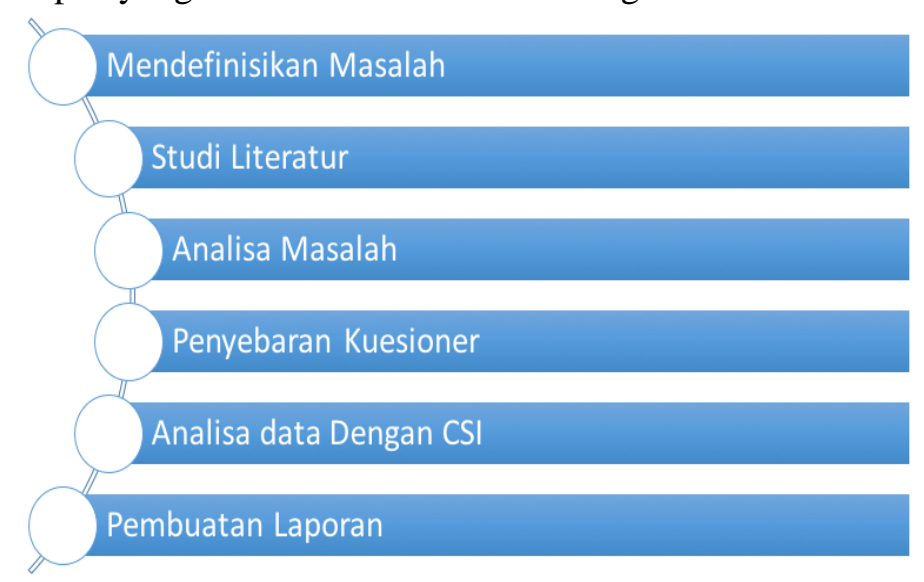

\section{Teknik Pengumpulan Data}

Gambar 1. Sistematika Penelitian

Metode pengambilan sampel dilakukan secara random bertahap (random multistage) dengan dua tahap. Tahap pertama adalah customer yang akan dijadikan sampel adalah customer yang telah menjadi member di Century Gym minimal 3 bulan. Selanjutnya pada tahap kedua, yaitu sampel yang memenuhi syarat pada tahap pertama akan diambil secara acak dengan ukuran sampel mengacu pada pendapat Slovin (Umar, 2005) dengan menggunakan rumus.

$$
\begin{array}{r}
\mathbf{n}=\frac{\mathbf{N}}{1+\left(\mathrm{Ne}^{2}\right)} \\
\text { Di mana: }
\end{array}
$$

$$
\begin{aligned}
\mathrm{n}= & \text { ukuran sampel } \\
\mathrm{N}= & \text { ukuran populasi } \\
\mathrm{e}= & \text { persen kelonggaran ketidaktelitian karena kesalahan pengambilan sampel yang } \\
& \text { masih dapat ditolerir dalam penelitian ditetapkan } 10 \% .
\end{aligned}
$$

Jadi besarnya sampel adalah sebagai berikut:

- Jumlah cutomer yang sudah memnjadi member di Century Gym adalah sebanyak 300 orang (tahap Pertama)

- Sedangkan jumlah yang memenuhi tahap kedua (menjadi member minimal 3 bulan) adalah 108 orang

$$
\begin{aligned}
& \mathrm{n}=\frac{108}{1+\left(108 \times 0.1^{2}\right)} \text { - } \\
& \text { Jadi jumlah sampel dalam penelitian ini adalah sebanyak } 52 \text { orang responden. }
\end{aligned}
$$

\section{Skala Pengukuran}

Skala pengukuran yang digunakan dalam penelitian adalah Skala Likert yang terdiri atas lima tingkat. Untuk penilaian tingkat kepentingan/harapan terdiri atas sangat penting (nilai 5), penting (nilai 4), cukup penting (nilai 3), kurang penting (nilai 2) dan tidak penting (nilai 1). Sedangkan untuk penilaian persepsi/kinerja terdiri atas sangat puas (nilai 5), puas (nilai 4), cukup puas (nilai 3), kurang puas (nilai 2) dan tidak puas (nilai 1). Jonathan (2006). 


\section{HASIL DAN PEMBAHASAN}

\section{Hasil Pengujian Validitas Instrumen}

Fungsi pengujian validitas instrumen penelitian adalah untuk mengetahui validitas setiap item kuisioner penelitian. Pengertian valid adalah bahwa kuisioner efektif dapat digunakan sebagai alat pengumpul data untuk menggali masalah yang dijadikan obyek penelitian. Efektifitas didasarkan pada asumsi bahwa kuisioner penelitian mudah dimengerti dan mudah dijawab oleh para responden penelitian. Pengukuran validitas instrumen penelitian dilakukan dengan menggunakan rumus koefisien korelasi Pearson Product Moment.

Kriterianya adalah jika $r$ hitung lebih besar dari $r$ tabel berarti valid, dan sebaliknya jika $r$ hitung lebih kecil dari $r$ tabel berarti tidak valid. Berdasarkan taraf kepercayaan (degree of freedom/df) yang dipilih sebesar 95 persen dan alpha 5 persen dengan jumlah sampel penelitian sebanyak $\mathrm{n}$ 52 responden untuk pelanggan, didapat $r$ tabel sebesar 0,444 . Untuk mengetahui koefisien korelasi validitas pada setiap item kuisioner penelitian dilakukan penghitungan dengan menggunakan bantuan program SPSS.

Tabel 1 Hasil Pengujian Validitas Instrumen Penelitian

\begin{tabular}{llll}
\hline No Item & Koefisien Kolerasi & R Kriti Product Moment & Hasil Pengujian \\
\hline 1 & 0,520 & 0,444 & Valid \\
\hline 2 & 0,856 & 0,444 & Valid \\
\hline 3 & 0,791 & 0,444 & Valid \\
\hline 4 & 0,702 & 0,444 & Valid \\
\hline 5 & 0,797 & 0,444 & Valid \\
\hline 6 & 0,715 & 0,444 & Valid \\
\hline 7 & 0,702 & 0,444 & Valid \\
\hline 8 & 0,791 & 0,444 & Valid \\
\hline 9 & 0,648 & 0,444 & Valid \\
\hline 10 & 0,856 & 0,444 & Valid \\
\hline 11 & 0,702 & 0,444 & Valid \\
\hline 12 & 0,791 & 0,444 & Valid \\
\hline 13 & 0,520 & 0,444 & Valid \\
\hline 14 & 0,791 & 0,444 & Valid \\
\hline 15 & 0,797 & 0,444 & Valid \\
\hline 17 & 0,797 & 0,444 & Valid \\
\hline 18 & 0,715 & 0,444 & Valid \\
\hline
\end{tabular}

Hasil pengujian koefisien korelasi validitas yang tertera pada tabel di atas dapat diketahui bahwa hasil penghitungan dengan bantuan software SPSS, didapatkan koefisien validitas seluruh item kuisioner penelitian yang disampaikan kepada para pihak yang menjadi sampel penelitian memenuhi kriteria valid, yakni hasil pengukuran koefisien validitas lebih besar dari angka penguji pada $\mathrm{r}$ tabel sebesar 0,444 .

Hal tersebut bermakna bahwa indikator-indikator penelitian dapat digunakan sebagai pengumpul data yang efektif untuk menggali masalah yang dijadikan obyek penelitian, dan selanjutnya dapat diolah untuk mengukur dimensi-dimensi kajian dan indikator-indikator penelitian untuk masing-masing dimensi kajian.

\section{Hasil Pengujian Reliabilitas Alat Ukur}

Pengujian reliabilitas alat ukur dimaksudkan untuk mengetahui nilai instrumen yang digunakan untuk mengumpulkan data primer dari sampel penelitian reliabel atau tidak reliabel. Pengertian reliabel adalah bahwa alat ukur yang digunakan dapat diandalkan, karena dalam situasi yang digunakan dapat diandalkan, karena dalam situasi yang berbeda kuisioner penelitian tidak menimbulkan persepsi yang jauh berbeda. 
Pengujian dengan kriteria jika $r$ hitung $<r$ tabel berarti tidak reliabel dan jika $r$ hitung $>r$ tabel berarti reliabel. Berdasarkan taraf kepercayaan (degree of freedom/df) yang dipilih 95 persen dan alpha 5 persen dengan jumlah sampel penelitian 52 responden Pelanggan didapat $r$ tabel sebesar 0,444. Koefisien korelasi reliabilitas yang diperoleh dari hasil penghitungan statistik dibandingkan dengan tabel harga kritik r product moment. Pengujian reliabilitas menggunakan teknik reliability analysist alpha yang dibantu dengan hasil penghitungan software SPSS.

Tabel 2 Hasil Pengujian realbilitas alat Ukur Penelitian

\begin{tabular}{cccc}
\hline No Item & Varian & $\begin{array}{c}\text { R Kritik Product } \\
\text { Moment }\end{array}$ & Heliabel \\
\hline 1 & 0,766 & 0,444 & Reliabel \\
\hline 2 & 0,537 & 0,444 & Reliabel \\
\hline 4 & 0,366 & 0,444 & Reliabel \\
\hline 5 & 0,303 & 0,444 & Reliabel \\
\hline 6 & 0,555 & 0,444 & Reliabel \\
\hline 7 & 0,358 & 0,444 & Reliabel \\
\hline 8 & 0,303 & 0,444 & Reliabel \\
\hline 9 & 0,366 & 0,444 & Reliabel \\
\hline 10 & 0,947 & 0,444 & Reliabel \\
\hline 11 & 0,537 & 0,444 & Reliabel \\
\hline 12 & 0,303 & 0,444 & Reliabel \\
\hline 13 & 0,366 & 0,444 & Reliabel \\
\hline 15 & 0,555 & 0,444 & Reliabel \\
\hline 16 & 0,766 & 0,444 & Reliabel \\
\hline 18 & 0,366 & 0,444 & Reliabel \\
\hline & 0,555 & 0,444 & Reliabel \\
\hline & 0,555 & 0,444 & Reliabel \\
\hline
\end{tabular}

\section{Pengukuran Kepuasan Pelanggan}

rangkuman untuk mengukur skor atau nilai total kepuasan pelanggan Century Gym tersebut. Setiap pertanyaan yang diajukan terdiri atas 5 (lima) kategori jawaban yaitu pilihan 1 berarti sangat tidak puas, pilihan 2 berarti tidak puas, pilihan 3 berarti netral, pilihan 4 berarti puas, dan pilihan 5 berarti sangat puas. Masing-masing kategori disusun berdasarkan skala Likert. Pilihan jawaban pertanyaan pertama lebih rendah bobotnya dari jawaban kedua, pilihan jawaban kedua lebih rendah bobotnya dari jawaban ketiga dan seterusnya. Data tersebut disajikan dalam Tabel berikut ini.

Tabel 3. Analisis Kepuasan Pelanggan Secara Keseluruhan

\begin{tabular}{lll}
\hline No & Aspek Kepuasan Kerja & Skor \\
\hline 1 & Ketersediaan tempat parkir memadai & 2,54 \\
\hline 2 & Kenyamanan ruang ganti & 2,83 \\
\hline 3 & Kebersihan Fasilitas & 2,50 \\
\hline 4 & Keleluasaan pemakaian alat fitness & 2,40 \\
\hline 5 & Ketepatan perbaikan alat fitness sesuai dengan waktu yang dijanjikan & 2,94 \\
\hline 6 & Ketepatan jam operasi tempat Gym & 2,62 \\
\hline 7 & Jumlah alat-alat fitness yang disediakan sesuai jumlah pelanggan & 2,73 \\
\hline 8 & Jumlah handuk yang disediakan sesuai dengan jumlah pelanggan & 2,58 \\
\hline 9 & Karyawan memberikan pelayanan secara cepat (perhitungan & pembayaran, \\
\hline & memberikan perlengkapan) & 2,62 \\
\hline 10 & Daya tanggap karyawan terhadap keluhan konsumen & 2,44 \\
\hline 11 & instruktur memberikan pelayanan dengan tanggap & 2,54 \\
\hline 12 & Pengetahuan karyawan tentang pelayanan yang disediakan & 2,58 \\
\hline 13 & Keramahan karyawan dan instruktur dalam melayani & 2,48 \\
\hline 14 & Adanya kegiatan promosi yang dilakukan Century gym & 2,58 \\
\hline 15 & Keamanan tempat parkir & 2,46 \\
\hline 16 & Kestrategisan tempat Century Gym & 2,54 \\
\hline 17 & Ketersediaan tempat untuk menyalurkan kritik dan saran bagi konsumen \\
\hline
\end{tabular}


Pengukuran Customer Satisfaction Index Terhadap Pelayanan ...

\begin{tabular}{ll}
\hline $18 \quad$ Kemudahan dalam melakukan transaksi pembayaran & 2,54 \\
\hline Total & $\mathbf{4 6 , 4 4}$ \\
\hline Rata-Rata & $\mathbf{2 , 5 8}$ \\
\hline
\end{tabular}

Dari tabel tersebut diatas dan berdasarkan tabel tingkat kepuasan pelanggan terlihat bahwa nilai rata-rata kepuasan pelanggan Century Gym adalah 2.58 atau berada pada tingkat kepuasan yang netral (biasa-biasa saja). Kondisi tingkat kepuasan ini harus ke depan harus bisa ditingkatkan, tentunya dengan mempertimbangkan setiap indicator kepuasan pelanggan serta perlu ditingkatkan fasilitas dan pelayanan Century Gym.

\section{Hubungan Antara Faktor-faktor Yang Mempengaruhi Kepuasan Pelanggan}

Dalam hal ini adalah kepuasan pelanggan sebagai variabel terikat/dependen yang disimbolkan dengan $Y_{2}$ terhadap variabel bebas/independen yang terdiri dari Bukti Fisik (Tangible) $\left(X_{1}\right)$, Keandalan (Reability) $\left(X_{2}\right)$, Daya Tangga (Responsiveness) ( $\left.X_{3}\right)$, Jaminan (Assurance) $\left(X_{4}\right)$, serta Empati (Emphaty) ( $X_{5}$ ) . Setelah mendapatkan model persamaan regresi sederhana kemudian dilakukan interpretasi terhadap model tersebut yang dilanjutkan dengan pengujian statistik yaitu terdiri dari Uji F, Uji T, dan Koefisien Determinasi $\left(R^{2}\right)$.

Tabel 4 Analisis Regresi Berganda X Terhadap $Y$

\begin{tabular}{llllll}
\hline \multirow{2}{*}{ Model } & \multicolumn{2}{l}{ Unstandardized Coefficients } & \multicolumn{2}{l}{$\begin{array}{l}\text { Standardized } \\
\text { Coefficients }\end{array}$} & \multirow{2}{*}{$\mathrm{S}$} \\
\cline { 2 - 5 } & $\mathrm{B}$ & Std. Error & Beta & \\
\hline 1Constant & 2.895 & 1.818 & & 1.932 & .331 \\
\hline $\mathrm{X} 1$ & .683 & .127 & .547 & 5.385 & 0 \\
\hline $\mathrm{X} 2$ & .157 & .122 & .129 & 3.284 & .011 \\
\hline $\mathrm{X} 3$ & .109 & .142 & .123 & 2.774 & .015 \\
\hline $\mathrm{X} 4$ & .017 & .08 & .021 & 3.211 & .009 \\
\hline $\mathrm{X} 5$ & .167 & .148 & .183 & 4.126 & .001 \\
\hline
\end{tabular}

Sehingga model persamaan regresi yang diperoleh adalah :

$\mathrm{Y} 2=2,895+0,683 \mathrm{X}_{1}+0,157 \mathrm{X}_{2}+0,109 \mathrm{X} 3+0,017 \mathrm{X}_{4}+0,167 \mathrm{X}_{5}$

Dimana : $\mathrm{Y}_{2}=$ Kepuasan pelanggan

$\mathrm{X}_{1}=$ Aspek Bukti Fisik (Tangible)

$\mathrm{X}_{2}=$ Aspek Keandalan (Reability)

$\mathrm{X}_{3}=$ Aspek Daya Tanggap (Responsiveness)

$\mathrm{X}_{4}=$ Aspek Jaminan (Assurance)

$\mathrm{X}_{5}=$ Aspek Empati (Emphaty)

Interpretasi dari model regresi yang diperoleh di atas adalah sebagai berikut :

1. Pengaruh aspek Bukti Fisik (Tangible) ( $\left.X_{1}\right)$ terhadap kepuasan Pelanggan Century Gym

Variabel Bukti Fisik memberikan pengaruh positif terhadap kepuasan pelanggan. Peningkatan Bukti Fisik (Tangible) sebesar 1 satuan akan meningkatkan kepuasan pelanggan sebesar 0,683 . Mengingat variabel ini memiliki pengaruh yang paling tinggi dari variabel bebas lainnya, maka untuk meningkatkan kepuasan pelanggan variabel ini harus mendapatkan perhatian yang lebih tinggi.

2. Pengaruh aspek keandalan (Reability) (X2) terhadap kepuasan Pelanggan Century Gym.

Variabel keadalan memberikan pengaruh negatif terhadap tingkat kepuasan. Peningkatan variabel keandalan sebanyak 1 satuan akan menurunkan kepuasan pelanggan sebanyak 0,157 .

3. Pengaruh aspek Daya Tanggap (Responsiveness) ( X3) terhadap kepuasan Pelanggan Century Gym 
Variabel Daya Tanggap memberikan pengaruh positif terhadap kepuasan pelanggan. Peningkatan Responsiveness sebanyak 1 satuan menyebabkan meningkatnya kepuasan pelanggan sebanyak 0,109 .

4. Pengaruh aspek Jaminan (Assurance) ( X4) terhadap kepuasan pelanggan Century Gym Variabel Jaminan memberikan pengaruh positif terhadap kepuasan pelanggan. Peningkatan pelayanan dari sisi Jaminan sebanyak 1 satuan akan meningkatkan kepuasan pelanggan sebanyak 0,017 .

5. Pengaruh aspek Emphaty (X5) terhadap kepuasan pelanggan Century Gym

Variabel Empati memberikan pengaruh positif terhadap kepuasan pelanggan. Peningkatan variabel ini sebanyak 1 satuan akan meningkatkan kepuasan pelanggan sebanyak 0,167.

\section{Uji F}

Uji F adalah uji untuk mengetahui besarnya pengaruh variabel independen terhadap variabel dependent secara bersama-sama. Dimana dalam hal ini hipotesis penelitian yang akan diselidiki adalah :

$H_{0}$ : Tidak ada pengaruh yang signifikan dari variabel independen terhadap variabel dependen (kepuasan).

$H_{1}$ : Terdapat pengaruh yang signifikan dari variabel independen terhadap variabel dependen (kepuasan).

Tabel 5. Ringkasan ANOVA Untuk Uji Signifikansi ANOVA $^{\mathrm{b}}$

\begin{tabular}{lllllll}
\hline \multirow{2}{*}{ Model } & $\begin{array}{l}\text { Sum } \\
\text { Squares }\end{array}$ & of & Mean Square & F & Sig. \\
\hline \multirow{3}{*}{1} & Regression & 844.229 & 6 & 140.705 & 8.843 & $.000^{\mathrm{a}}$ \\
\cline { 2 - 7 } & Residual & 1463.851 & 92 & 15.911 & & \\
\cline { 2 - 7 } & Total & 2308.081 & 98 & & \\
\hline
\end{tabular}

Nilai F hitung diperoleh sebesar 8,843 dan F tabel untuk $\mathrm{N}(1)=6$ dan $\mathrm{N}(2)=52$ diperoleh nilai sebesar 2,28. Berdasarkan hasil perhitungan di atas berarti nilai $\mathrm{F}$ hitung lebih besar dari nilai $\mathrm{F}$ table $(8,843>2,28)$, dengan nilai probabilitas untuk $F$ statistik (signifikansi) adalah $0,000000<$ $\alpha=0,05$. Hal ini berarti seluruh variabel independen yakni Bukti Fisik (Tangible), Keandalan (Reliability), Daya Tanggap (Responsiveness) Jaminan (Assurance) dan Empati (Emphaty) secara bersama-sama signifikan mempengaruhi variabel dependen kepuasan pelanggan pada tingkat signifikansi $\alpha=5 \%$.

\section{Uji T}

Uji t adalah uji secara individual semua koefisien regresi yang bertujuan untuk mengetahui besarnya pengaruh dari masing-masing variabel independent terhadap variabel dependent. Uji signifikansi t dilihat dari nilai prob yang dibandingkan dengan nilai tingkat signifikansi $\alpha=$ 0,05 . Bila prob $<\alpha$, maka variable tersebut signifikan.

Tabel 6 Tabel t-Test dan Tingkat Signifikansi Masing-masing Variabel

\begin{tabular}{llll}
\hline Variabel & t hitung & Prob & Signifikansi \\
\hline Bukti Fisik (Tangible) & 5,385 & .000 & Signifikan \\
\hline Keandalan (Reability) & 3,284 & .011 & Signifikan \\
\hline \begin{tabular}{l} 
Daya $\begin{array}{l}\text { Tanggap } \\
\text { Responsiveness) }\end{array}$ \\
\hline Jaminan (Assurance)
\end{tabular} & 2,774 & .015 & Signifikan \\
\hline Empati (emphaty) & 3,211 & .009 & Signifikan \\
\hline
\end{tabular}

Berdasarkan hasil uji signifikansi diperoleh bahwa keseluruhan variabel yang ada signifikan mempengaruhi tingkat kepuasan pelanggan sebagai pelanggan internal. 


\section{Koefisien Determinasi $\left(\mathbf{R}_{2}\right)$}

Koefisien determinasi digunakan untuk mengetahui berapa persen perubahan variabel independen dapat menjelaskan perubahan variabel dependennya. Dari pengujian yang dilakukan, nilai $\mathrm{R}_{2}$ Ajusted sebesar 0,325, sehingga dapat dikatakan bahwa sebesar 32,50\% variasi variabel dependen (dalam hal ini kepuasan pelanggan Century Gym) dapat dijelaskan oleh variabel independen Bukti Fisik (Tangible), Keandalan (Reliability), Daya Tanggap (Responsiveness) Jaminan (Assurance) dan Empati (Emphaty). Sedangkan sisanya sebesar $67,5 \%$ dijelaskan oleh variabel lain di luar model.

Tabel 7 Koefisien Determinasi $\left(R_{2}\right)$

Model Summary ${ }^{b}$

\begin{tabular}{|c|c|c|c|c|c|}
\hline Model & $\mathrm{R}$ & R Square & $\begin{array}{l}\text { Adjusted } \\
\text { Square }\end{array}$ & $\mathrm{R}$ & $\begin{array}{l}\text { Std. Error of } \\
\text { the Estimate }\end{array}$ \\
\hline 1 & $.605^{\mathrm{a}}$ & .366 & .324 & & 3.989 \\
\hline
\end{tabular}

\section{Uji Normalitas}

Uji normalitas bertujuan untuk menguji apakah dalam sebuah model regresi, variabel dependent, variabel independent atau keduanya mempunyai distribusi normal ataukah tidak. Model regresi yang baik adalah distribusi data normal atau mendekati normal. Sebagai dasar bahwa uji $\mathrm{t}$ dan uji $\mathrm{F}$ mengasumsikan bahwa nilai residual mengikuti distribusi normal. Jika asumsi ini dilanggar maka model regresi dianggap tidak valid dengan jumlah sampel yang ada. Ada dua cara yang biasa digunakan untuk menguji normalitas model regresi tersebut yaitu dengan analisis grafik (normal P-P plot) dan analisis statistik (analisis Z skor skewness dan kurtosis) serta One Sample Kolmogorov-Smirnov Test.

Tabel 8 Model Nilai Skewness-Kurtosis Regresi $\left(Y_{2}\right)$

\begin{tabular}{lllll}
\hline & \multicolumn{3}{l}{ Skewness } & Kurtosis \\
\cline { 2 - 5 } & Statistic & Std. Error & Statistic & Std. Error \\
\hline $\begin{array}{l}\text { Unstandardized Residual Valid N } \\
\text { (listwise) }\end{array}$ & .045 & .274 & -.653 & .541 \\
\hline
\end{tabular}

Dari hasil pengolahan data dengan bantuan software SPSS, dapat diketahui bahwa rasio Skewness (kemiringan) sebesar 0,045/0,274 $=0,164$ sedangkan rasio Kurtosis (keruncingan) sebesar $-0,653 / 0,541=-1,207$. Sebagai syarat bahwa data berdistribusi normal, nilai rasio Skewness dan rasio Kurtosis berada pada -2 hingga +2 . Merujuk pada nilai yang diperoleh maka data memenuhi syarat berdistribusi normal.

Apabila dilihat pada hasil One-Sample Kolmogorov-Smirnov Test di bawah ini, terlihat bahwa nilai P-value yaitu Asymp.Sig (2-tailed) bernilai 0.841>0.05. sehingga disimpulkan bahwa residual telah memenuhi asumsi distribusi normal.

Tabel 9 Uji Kolmogorov-Smirnov

\begin{tabular}{llll}
\hline & & Unstandardized Residual & \\
\hline $\mathrm{N}$ & & 52 \\
Normal Parameters $^{\mathrm{a}}$ & Mean & .0000000 & \\
& Std. Deviation & 3.79930418 & $.064-$ \\
\hline Most Extreme Differences & Absolute Positive & .070 & .070 \\
& Negative & & \\
& & .617 & \\
\hline Kolmogorov-Smirnov Z & & .841 \\
\hline Asymp. Sig. (2-tailed) & & \\
\hline
\end{tabular}




\section{Uji Autokorelasi}

Uji autokorelasi adalah untuk melihat apakah terjadi korelasi antara suatu periode $t$ dengan periode sebelumnya (t-1). Secara sederhana adalah bahwa analisis regresi adalah untuk melihat pengaruh antara variabel bebas terhadap variabel terikat, jadi tidak boleh ada korelasi antara observasi dengan data observasi sebelumnya. Jika terjadi korelasi maka dinamakan ada problem autokorelasi. Dalam hal ini cara untuk mendeteksi gejala autokorelasi yaitu uji Durbin Watson (DW test). Syarat tidak terjadi gejala autokorelasi adalah nilai DW lebih besar atau sama dengan nilai $d u$ dan lebih kecil dari nilai $4-d u$. Atau dengan kata lain syarat tidak terjadi autokorelasi adalah nilai DW berada diantara $d u \leq \mathrm{DW} \leq 4-d u$.

Tabel 10 Nilai Durbin Watson Pada Model Summary

\begin{tabular}{llllll}
\hline & & & Adjusted R & Std. Error of & Durbin- \\
\hline Model & R & R Square & Square & the Estimate & Watson \\
\hline 1 & $.605^{\text {a }}$ & 0.366 & 0.324 & 3.989 & 1.905 \\
\hline
\end{tabular}

Dari hasil pengolahan data, diperoleh nilai Durbin-Watson (DW) sebesar 1,905. Jumlah sampel penelitian adalah 52 responden dengan jumlah variabel bebas sebanyak 6. Apabila melihat nilai DW pada table untuk $\mathrm{n}=52$ dengan $\mathrm{k}=6$, diperoleh nilai $\mathrm{dl}=1,3090$ dan nilai du $=1,8183$. Nilai DW hitung adalah sebesar 1,905 berarti DW lebih besar dari $d u$ dan lebih kecil dari 4- $d u$ yaitu 2,1817 . Nilai DW ini terletak diantara $d u$ dan (4- $d u$ ) sehingga dapat disimpulkan bahwa dalam hal ini tidak terjadi autokorelasi.

\section{Uji Multikolinearitas}

Uji multikolinearitas bertujuan untuk menguji apakah model regresi ditemukan adanya korelasi antar variabel bebas (independent variable). Model regresi yang baik seharusnya tidak terjadi korelasi di antara variabel bebas, karena jika hal tersebut terjadi maka variabel-variabel tersebut tidak ortogonal atau terjadi kemiripan. Variabel ortogonal adalah variabel bebas yang nilai korelasi antar sesama variabel bebas bernilai nol. Uji ini untuk menghindari kebiasan dalam proses pengambilan keputusan mengenai pengaruh parsial masing-masing variabel independen terhadap variabel dependen. Untuk mendeteksi apakah terjadi problem multikol dapat melihat nilai tolerance dan lawannya variace inflation factor (VIF). Uji Multikolinearitas dilakukan dengan melihat nilai tolerance dan variance inflation factor (VIF) dari hasil analisis dengan menggunakan SPSS. Apabila nilai tolerance value lebih tinggi daripada 0,10 atau VIF lebih kecil daripada 10 maka dapat disimpulkan tidak terjadi multikolinearitas.

Tabel 11 Nilai Toleransi dan VIF

\begin{tabular}{ccccc}
\hline \multirow{2}{*}{ Model } & \multicolumn{4}{c}{ Collinearity Statistics } \\
\cline { 2 - 5 } & Tolerance & & VIF \\
\hline 1 Constant & & 1.161 & \\
X1 & .861 & 1.139 & \\
X2 & .878 & 2.853 & \\
X3 & .35 & 1.098 & \\
X4 & .911 & 2.984 \\
X5 & .335 & \\
\hline
\end{tabular}

Dari hasil pengolahan data, terlihat bahwa nilai VIF untuk kelima variabel bebas lebih kecil dari 10 dan lebih berada berada disekitar nilai 1 dan 2, sehingga dapat disimpulkan bahwa dalam hal ini tidak terjadi multikolinieritas.

\section{Uji Heteroskedastisitas}

Uji heteroskedastisitas bertujuan menguji apakah dalam model regresi terjadi ketidaksamaan veriance dari residual satu pengamatan ke pengamatan yang lain. Jika variance 
tetap maka disebut homoskedastisitas dan jika berbeda maka terjadi problem heteroskedastisitas. Model regresi yang baik yaitu homoskesdatisitas atau tidak terjadi heteroskedastisitas. Ada beberapa cara untuk mendeteksi ada tidaknya heteroskedastisitas yaitu melihat scatter plot (nilai prediksi dependen ZPRED dengan residual SRESID)

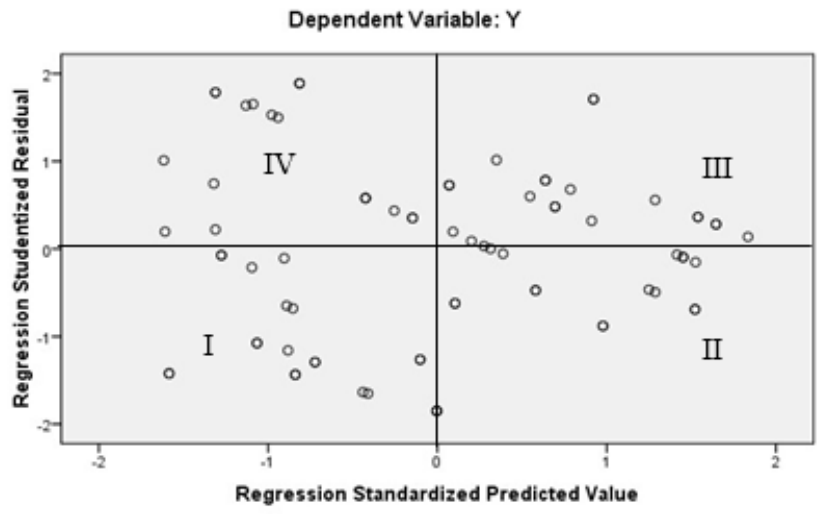

Gambar 2 Diagram Scatterplot Untuk Uji Heteroskedastisitas

Berdasarkan hasil pengolahan data dengan melihat diagram Scatter plot di atas, nampak bahwa data tidak membentuk suatu pola tertentu dan tersebar bebas di kuadran I, II, III, dan IV sehingga dapat disimpulkan bahwa dalam hal ini tidak terjadi gejala heteroskedastisitas.

Dari hasil uji asumsi klasik terhadap model persamaan regresi untuk Y2 (Pelanggan Century Gym), yang meliputi uji normalitas, uji autokorelasi, uji multikolinearitas, dan uji heteroskedastisitas, model persamaan regresi tersebut telah memenuhi persyaratan untuk keseluruhan kriteria yang dipersyaratkan. Sehingga dapat disimpulkan bahwa model persamaan regresi tersebut bisa disebut model yang baik karena telah memenuhi kriteria Best Linear Unbiased Estimator (BLUE).

\section{KESIMPULAN}

Berdasarkan Penelitian yang telah dilakukan dapat diambil kesimpulan sebagai berikut:

1. Tingkat kepuasan pelanggan Century Gym secara keseluruhan berada pada kategori tidak puas dengan nilai/skor sebesar 50,20\%.

2. Tingkat kepuasan pelanggan pelanggan Century Gym secara keseluruhan berada pada kategori netral dengan nilai/skor sebesar 3,35.

3. Faktor yang paling mempengaruhi kepuasan pelanggan adalah Bukti Fisik (Tangible) yaitu sebesar 0,683 seperti ditunjukkan pada persamaan regresi $=2,895+0,683+0,157+$ $0,109+0,017+0,167+0,107$

4. Hasil uji F simultan dan uji t parsial dari model persamaan regresi kepuasan pelanggan menunjukkan bahwa seluruh variabel independen secara bersama-sama signifikan mempengaruhi variabel dependen yaitu kepuasan pelanggan pada tingkat signifikansi $\alpha$ $=5 \%$.

\section{DAFTAR PUSTAKA}

[1]. Aditiawarman, B. P. 2000. Pengukuran Tingkat Kepuasan dan Identifikasi Ketidakpuasan Pelayanan (Studi Kasus : Saving and Lending Unit Sucofindo). Skripsi pada Departemen Matematika dan Ilmu Pengetahuan Alam, Institut Pertanian Bogor, Bogor. 
[2]. Antari Setiyawati. Studi Kepuasan Pelanggan Untuk Mencapai Loyalitas Pelanggan (Studi Kasus pada Konsumen Toko Bangunan Bangun Rejeki Semarang). Semarang, Universitas Dipenogoro; Tahun 2009.

[3]. Arry Twadikaryanto Sudiarso. Analisis Kepuasan Konsumen Terhadap Atribut Pondok Seafood di Muara Karang Jakarta Utara. Fakultas Pertanian. Bogor : Institut Pertanian Bogor. Program Sarjana Ekstensi Manajemen Agribisnis; 2008.

[4]. Astriani, D. 2008. Analisis Kepuasan Pelanggan Restoran Gurih 7. Skripsi Fakultas Teknologi Pertanian. IPB. Bogor.

[ 5]. Budi Harijanto, Yuri Ariyanto. Sistem Informasi Pengukuran Kepuasan Pelanggan (Studi Kasus Politeknik Negeri Malang). Jurnal ELTEK. Tahun 2014 ; Vol 12(2).

[6]. Engel, et, al,. 1995. Consumer Behaviour. 8th Eidition Forth Worth, Texas: The Dryden Press.

[7]. Ferninda Manoppo. Kualitas Pelayanan, dan Servicescape Pengaruhnya Terhadap Kepuasan Konsumen Pada Hotel Gran Puri Manado. Jurnal EMBA. Tahun 2013; Vol 1(4): 1343.

[8]. Hedithya Novel, Humala L. Napitupulu, DEA. Penilaian Tingkat Kepuasan Pasien Terhadap Pelayanan Jasa Puskesmas Medan Johor Dengan Metode Servperf. e-Jurnal Teknik Industri FT USU. Tahun 2013 : Vol 3 (2) : 18-22.

[9]. Irawan, H. 2003. Indonesian Customer Satisfaction. Jakarta: PT Gramedia Pustaka Utama.

[ 10]. Riandina Wahyu Oktaviani, Rita Nurmalina Suryana. Analisis Kepuasan Pengunjung dan Pengembangan Fasilitas Wisata Agro (Studi Kasus di Kebun Wisata Pasirmukti, Bogor). Jurnal agro ekonomi. Tahun 2008 : Vol 24(1) : 41-58.

[11]. Pusat Jaminan Mutu. Instruksi Kerja Pengolahan Data Kepuasan Pelanggan. STIKOM Bali. 09 Desember 2015.:

[12]. Supranto, J. 2001. Pengukuran Tingkat Kepuasan Pelanggan untuk Menaikkan Pangsa Pasar. Jakarta: PT. Rineka Cipta.

[13]. Supranto J. 2001. Pengukuran Tingkat Kepuasan Pelanggan. Bineka Cipta. Jakarta.

[14]. Teguh Aditya P., Taufik R., Nurhaidar R. Analisis Kepuasan Konsumen Food Bar Kabupaten Subang. Prosiding Seminar Nasional Penelitian dan PKM Sains, Teknologi dan Kesehatan. Tahun 2011 ; Vol 2 (1) : Hal 313 - 314.

[15]. Tiena G. Amran, Ponti Ekadeputra. Pengukuran Kepuasan Pelanggan Menggunakan Metode Kano dan Root Cause Analysis (Studi Kasus PLN Tanggerang). Jurnal Teknik Industri. ISSN : 1411 - 6340.

[16]. Yola, M dan Budianto, D. 2013.Analisis Kepuasan Konsumen Terhadap Kualitas Pelayanan Dan Harga Produk Pada Supermarket Dengan Menggunakan Metode Importance Performance Analysis (IPA).Jurnal Optimasi Sistem Industri 12(2):301- 309 